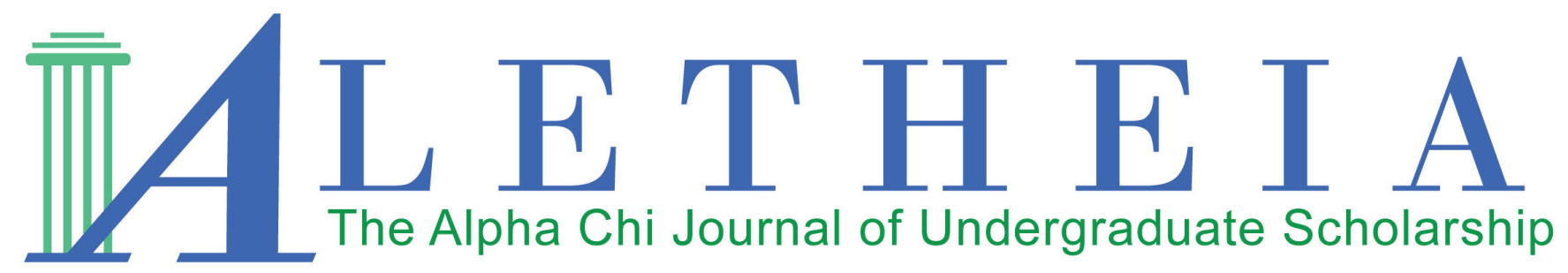

Volume 3 | Issue 2 | 2018

\title{
The Relationship between Foreign Direct Investment and Economic Growth in Emerging Economies
}

\author{
Richardson \& Rana \\ Colby-Sawyer College \\ New Hampshire Alpha Chapter
}

Vol. 3(2), 2018

Title: The Relationship between Foreign Direct Investment and Economic Growth in Emerging Economies

DOI:

ISSN: $2381-800 \mathrm{X}$

Keywords: Foreign Direct Investment, Economic Growth (by GDP) [per capita]

This work is licensed under a Creative Commons Attribution 4.0 International License.

Author contact information is available from tlindblom@alphachihonor.org or kvosevich@alphachihonor.org

\section{Aletheia-The Alpha Chi Journal of Undergraduate Scholarship}

- This publication is an online, peer-reviewed, interdisciplinary undergraduate journal, whose mission is to promote high quality research and scholarship among undergraduates by showcasing exemplary work.

- Submissions can be in any basic or applied field of study, including the physical and life sciences, the social sciences, the humanities, education, engineering, and the arts.

- Publication in Aletheia will recognize students who excel academically and foster mentor/mentee relationships between faculty and students.

- In keeping with the strong tradition of student involvement in all levels of Alpha Chi, the journal will also provide a forum for students to become actively involved in the writing, peer review, and publication process.

- More information can be found at www.alphachihonor.org/aletheia. Questions to the editors may be directed to tlindblom@alphachihonor.org orkvosevich@alphachihonor.org.

\footnotetext{
Alpha Chi is a national college honor society that admits students from all academic disciplines, with membership limited to the top 10 percent of an institution's juniors, seniors, and graduate students. Invitation to membership comes only through an institutional chapter. A college seeking a chapter must grant baccalaureate degrees and be regionally accredited. Some 300 chapters, located in almost every state, induct approximately 11,000 members annually. Alpha Chi members have been "making scholarship effective for good" since 1922.
} 
Title: The Relationship between Foreign Direct Investment and Economic Growth in Emerging Economies DOI:

ISSN: $2381-800 \mathrm{X}$

This work is licensed under a Creative Commons Attribution 4.0 International License.

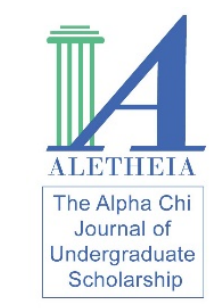

\author{
The Relationship between Foreign Direct Investment and \\ Economic Growth in Emerging Economies \\ Richardson ${ }^{1} \&$ Rana \\ Colby-Sawyer University
}

\begin{abstract}
This research paper investigates the relationship between Foreign Direct Investment (FDI) and Economic Growth (EG), as measured by Gross Domestic Product (GDP), in emerging economies. For the purpose of this study, the term 'emerging economies' refers to countries that exhibit sustainable per capita income growth, according to the basic minimum criteria established by Bigsten \& Kayizzi-Mugerwa (1999). The thirty countries observed and discussed were drawn from the J.P. Morgan Emerging Markets Bond Index (EMBI), Morgan Stanley Capital International's (MSCI) Emerging Markets Index and Bloomberg's 2013 list of the 'Top 20 Emerging Markets'. In previous research, although multiple authors have traced a positive relationship between FDI and GDP, a conclusive causal relationship has not been established (Nandi, 2012). This paper will examine FDI growth trends across the 30 select countries for a correlation with GDP growth. A subsequent regression analysis will help determine whether the case for a causal relationship can be founded.
\end{abstract}

\title{
Keywords: Foreign Direct Investment, Economic Growth (by GDP) [per capita]
}

\section{Introduction}

The concept of Foreign Direct Investment (FDI) has gained global traction, having evolved from the instrumental role played by economic superpowers ${ }^{2}$ like the United States since the mid $20^{\text {th }}$ Century. However, the notion itself dates far back in history, even to the commercial activities of Sumerian merchants in 2500 B.C. (Lipsey, 2001). As of 2016, worldwide FDI activities amount to an estimated $\$ 2.3$ trillion, nearly $3 \%$ of total global output (World Bank, 2018). Recently, rising economic powers such as the BRICS ${ }^{3}$ have become more receptive to the idea of engaging foreign corporations in business operations that yield benefits to both the host nation and the entrant corporation. These developments are in an effort to attract attention to lesser-known economies and to create new opportunities [for productivity and employment] that would otherwise be unattainable.

Several studies have been conducted to assess the economic impact of FDI on host countries, and to describe a relationship between FDI and Economic Growth (EG). While Almfraji and Almsafir (2014), in their work, argue for a positive relationship between FDI and E.G., Encinas-Ferrer and Villegas-Zermeño (2015) identify a bi-directional relationship between the two factors. Beyond that, another issue of contention is the

\footnotetext{
${ }^{1}$ Wesson Honors Program. Colby-Sawyer College. 541 Main St., New London, NH 03257, USA.

Email: kevin.richardson@my.colby-sawyer.edu. Phone: (484) 326-8256.

${ }^{2}$ Economic Superpowers are the largest economies around the world with substantial influence on global economic activity and policy. They include the US, China, Japan, Germany, UK, France, India, Italy, Brazil, Canada.

${ }^{3}$ BRICS refers to Brazil, Russia, India, China and South Africa.
} 
question of causality: Does FDI actually cause EG? It is difficult and impractical to speak broadly to global patterns due to variations in culture, political influence, and technology levels across geographic regions. In this paper, the authors set out to analyze emerging economies, categorized by geographic and economic ties: BRICS, Africa, Asia, Europe, and South America. In addition, the authors explore the case for Mexico, weighing in on a broader scholarly conversation about the substantial flows in investment following a deregulation campaign in the 1980s, and the pursuance of the North American Free Trade Agreement (Waldkirch, 2008).

\section{Methods}

The authors of this paper intend to address two questions, concerning the nature of the relationship between FDI and EG, and whether a causal relationship exists. Both topics continue to inspire debate within academic circles and in economic journals, often on the techniques employed to conduct an accurate assessment. This paper posits that a perfect depiction of such a relationship is nearly impossible to delineate, owing to the complexity of the unquantifiable, qualitative variations earlier mentioned. Nonetheless, this research applies two primary statistical approaches in an attempt to resolve these questions.

\section{Conjugate (Linear Graph)}

We compiled a spreadsheet of FDI data from the World Bank database, indicating net inflows, as well as GDP in US dollars for each of the 30 countries, going back 30 years (from 1987-2016). From this dataset, we have computed FDI per capita and GDP per capita, derived by dividing FDI and GDP each by annual population respectively. Due to the enormity of the data, we constructed a Pivot Table to summarize the information, from which we developed Pivot Charts. We plot GDP per capita and FDI per capita on separate vertical axes of a linear graph, to account for the disparity in scales, against time (Years 1987 to 2016) on the horizontal axis. The purpose of this graph is to illustrate the direction of both variables, i.e. if FDI per capita and GDP per capita tend to rise and fall in similar patterns over the 30-year period.

\section{Regression Analysis}

The next step involves a second Pivot Table, from which we plot FDI against GDP in another linear graph. This graph, rather than merely showing trends, seeks to explain the extent of causality between FDI and GDP. The graph shows an R-squared value, "a statistical metric that explains how much of the variability of a factor can be caused by its relationship to another factor" (Business Dictionary). R-squared values range from $0-100 \%$, where a value closer to $100 \%$ implies that the variability of the data around the mean (relationship) can be explained by the model. A value approaching $0 \%$ tells otherwise (that the model does not necessarily explain the relationship). This method will be critical in helping determine a causal relationship between FDI and GDP.

\section{Analysis}

\section{The Case for BRICS}

The BRICS nations, sometimes referred to as potential superpowers, are a group of rapidly evolving countries that span the continents of Africa, Asia, Europe and South America. Table 1.1 presents the most recent (as of 2016) GDPs for each of these nations, ranging from South Africa at $\$ 295$ billion to China at $\$ 11.2$ trillion. Despite the significant margins in GDP, these five collectively account for $22 \%$ of global output ${ }^{4}$ in 2016 (World Bank, 2018). The relatively lower levels in GDP and FDI especially in South Africa, are a consequence of factors, including, but not limited to, the fact that South Africa only became a sovereign state in 1960. Additionally, lags in technological advancement, as Malikane and Chitambara (2017) write, hamper the ease of doing business in certain regions than others. That notwithstanding, Jadhav (2012) contends, "most of the investment in BRICS is motivated by market-seeking purpose..." [or classical economics] as opposed to secondary factors.

\footnotetext{
${ }^{4}$ The term 'output' is used here to refer to GDP.
} 


\begin{tabular}{|c|r|r|}
\hline COUNTRY & \multicolumn{1}{|c|}{2016 GDP (USD) } & \multicolumn{1}{c|}{2016 FDI (USD) } \\
\hline China & $11,199,145,157,649.20$ & $170,556,525,654.03$ \\
\hline India & $2,263,792,499,341.01$ & $44,458,571,545.80$ \\
\hline Brazil & $1,796,186,586,414.45$ & $78,167,247,014.61$ \\
\hline Russia & $1,262,759,893,596.58$ & $32,538,900,000.00$ \\
\hline South Africa & $295,456,189,492.01$ & $2,250,190,584.26$ \\
\hline
\end{tabular}

Table 1.1: 2016 GDP and FDI for BRICS countries by magnitude (USD)

In Figure 1.1 below, the linear graph illustrates a generally positive correlation between FDI per capita and GDP per capita over time among the BRICS countries. This is evidenced by the closely tied patterns in orange and blue lines (see chart legend). In simple terms, between 1987 and 2016, GDP per capita tended to rise and fall in a similar fashion to FDI per capita. Figure 1.2 responds to the question of a causal relationship. The R-squared value derived from the trendline and equation of the line is 0.4804 . This implies that $48.04 \%$ of GDP among the BRICS, over the period of study, can be attributed to FDI activities, whereas the remaining $51.96 \%$ of GDP is the result of other factors. FDI in the BRICS countries decreased substantially during the 2007-08 Financial Crisis, consistent with global macro trends (World Bank, 2018). By 2010, India was the only country out of the pool that had not recovered from the crisis (Nandi, 2012). However, the country has since bounced back and is now considered a major investment hub after the United States and China (Teli, 2014).

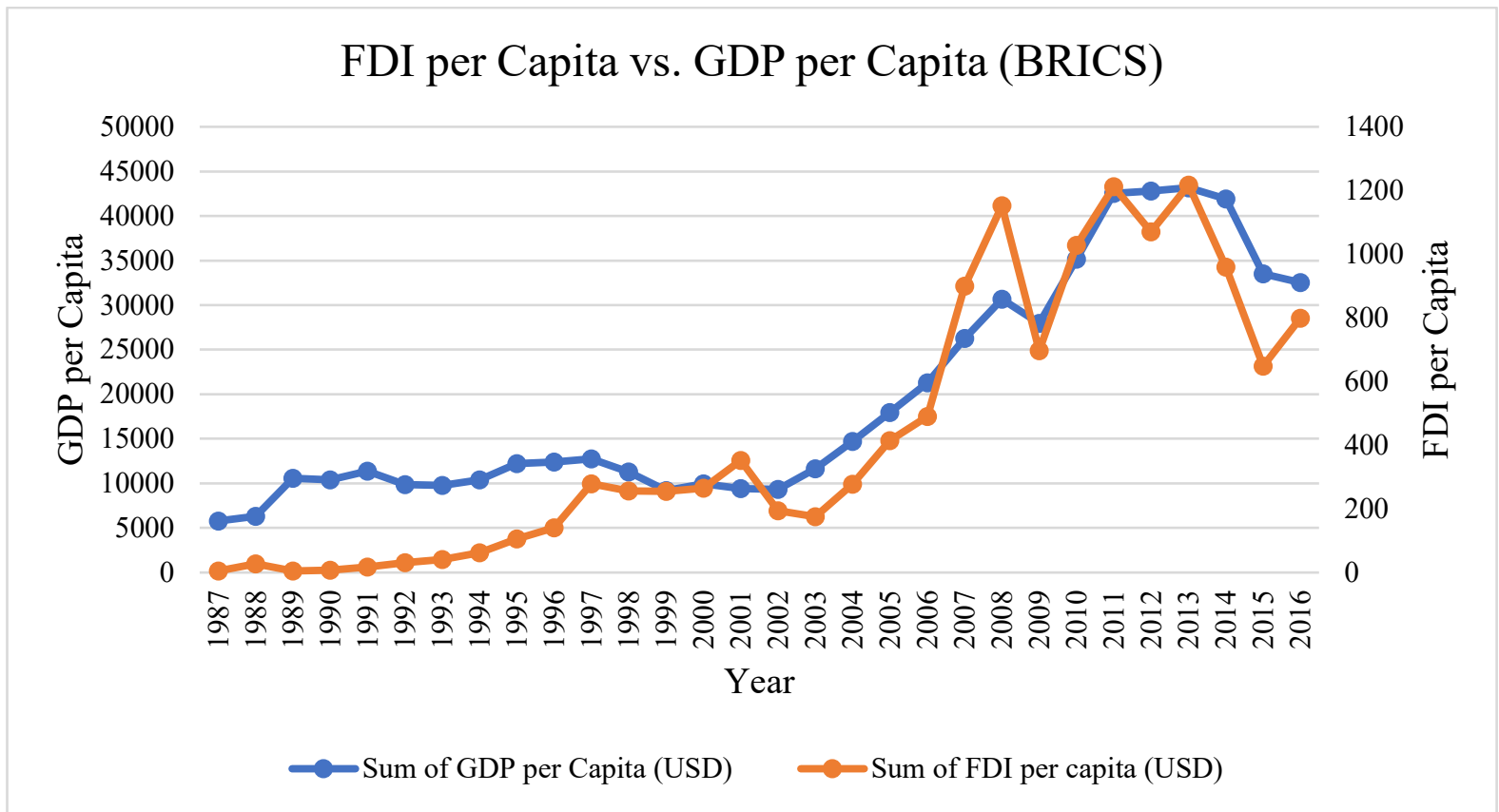

Figure 1.1: Correlation of GDP per capita and FDI per capita among BRICS (1987-2016) 


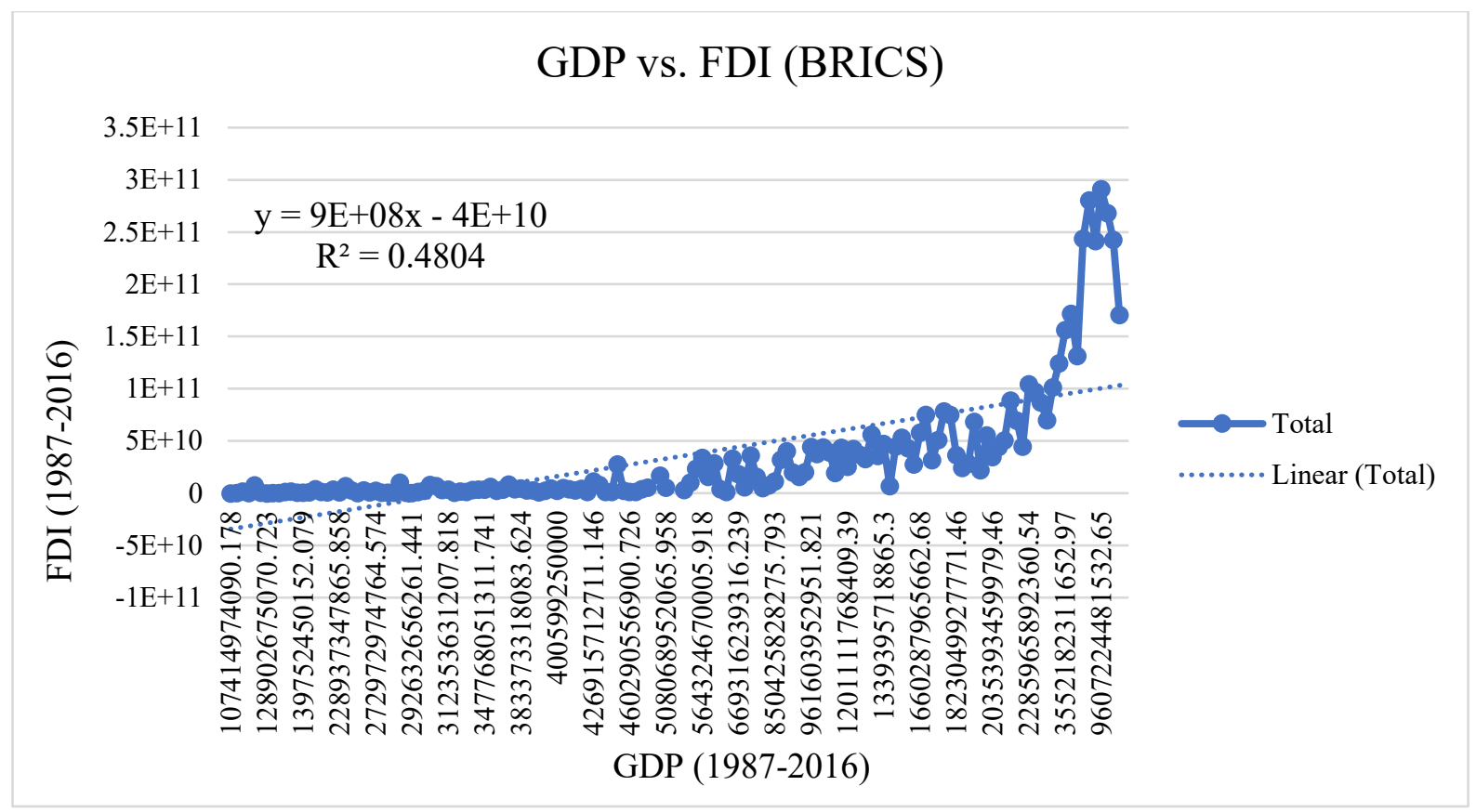

Figure 1.2: FDI vs. GDP among BRICS (1987-2016)

\section{The Case for Africa}

Most African countries are former colonies of Western economic powers such as Great Britain and France. It was not until the mid $20^{\text {th }}$ Century that nations like Egypt, Libya, Morocco and Ghana gained political independence. However, the developments of that era did not immediately translate into economic freedom. As Bertocchi and Canova (2002) discuss in their work on colonization and Africa's growth, "colonial powers built infrastructure to integrate Africa into the world economy, ...mainly for extraction purposes." Despite the late start, this study features seven African nations that have demonstrated over the years strong, sustainable economic growth (see Table 2.1). Other fast-growing African nations that have begun to emerge in the limelight are Ethiopia, Ivory Coast, Senegal and Tanzania (Quartz, 2018).

\begin{tabular}{|l|r|r|}
\hline \multirow{2}{*}{ COUNTRY } & \multicolumn{2}{|c|}{ PER CAPITA INCOME } \\
\cline { 2 - 3 } & $\% \Delta$ in GDP (1987-2016) & $\% \Delta$ in FDI (1987-2016) \\
\hline Egypt & $356 \%$ & $374 \%$ \\
\hline Ghana & $302 \%$ & $35343 \%$ \\
\hline Morocco & $208 \%$ & $2492 \%$ \\
\hline Namibia & $138 \%$ & $88982 \%$ \\
\hline Nigeria & $696 \%$ & $244 \%$ \\
\hline South Africa & $70 \%$ & $624 \%$ \\
\hline Zambia & $313 \%$ & $841 \%$ \\
\hline
\end{tabular}

Table 2.1: Percentage changes comparing 2016 GDP and FDI data to 1987 data

Among the seven African countries in this study, our conjugate model illustrates, in Figure 2.1 below, a strong association between and FDI and GDP [per capita] trends over the last three decades. As in the case of the BRICS, these two variables mirror each other closely. In the subsequent regression (Figure 2.2), our research finds that FDI activities among these emerging African countries account for $40.58 \%$ of GDP over the last 30 years. This is a rational finding, given Africa's prevalent challenges with corporate governance, infrastructure and regulatory environments that are presently not as conducive for investments as found in developed nations (Krishnakumar, Sethi \& Chidambaran, 2014). Other major factors that contribute to Africa's GDP include the 
continent's high dependence on natural resources such as minerals, and especially agricultural produce. "Ghana is a good example of a country with a long history of resource-dependence... after the discovery of offshore oil in 2007, [it] has become more dependent on the natural resource sector to drive growth (Bhorat, Chelwa, Naidoo \& Stanwix, 2015).

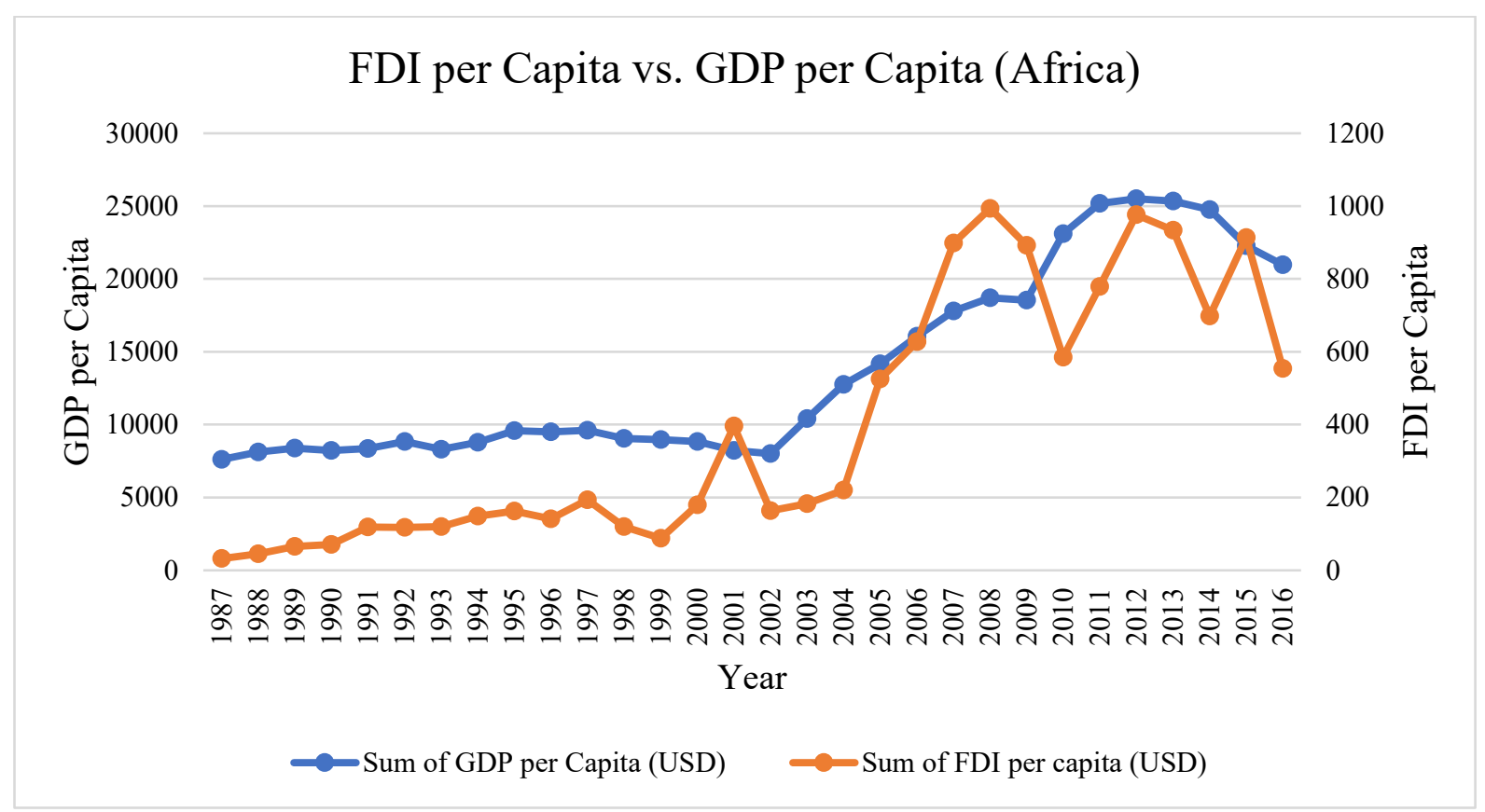

Figure 2.1: Correlation of GDP per capita and FDI per capita in Africa (1987-2016)

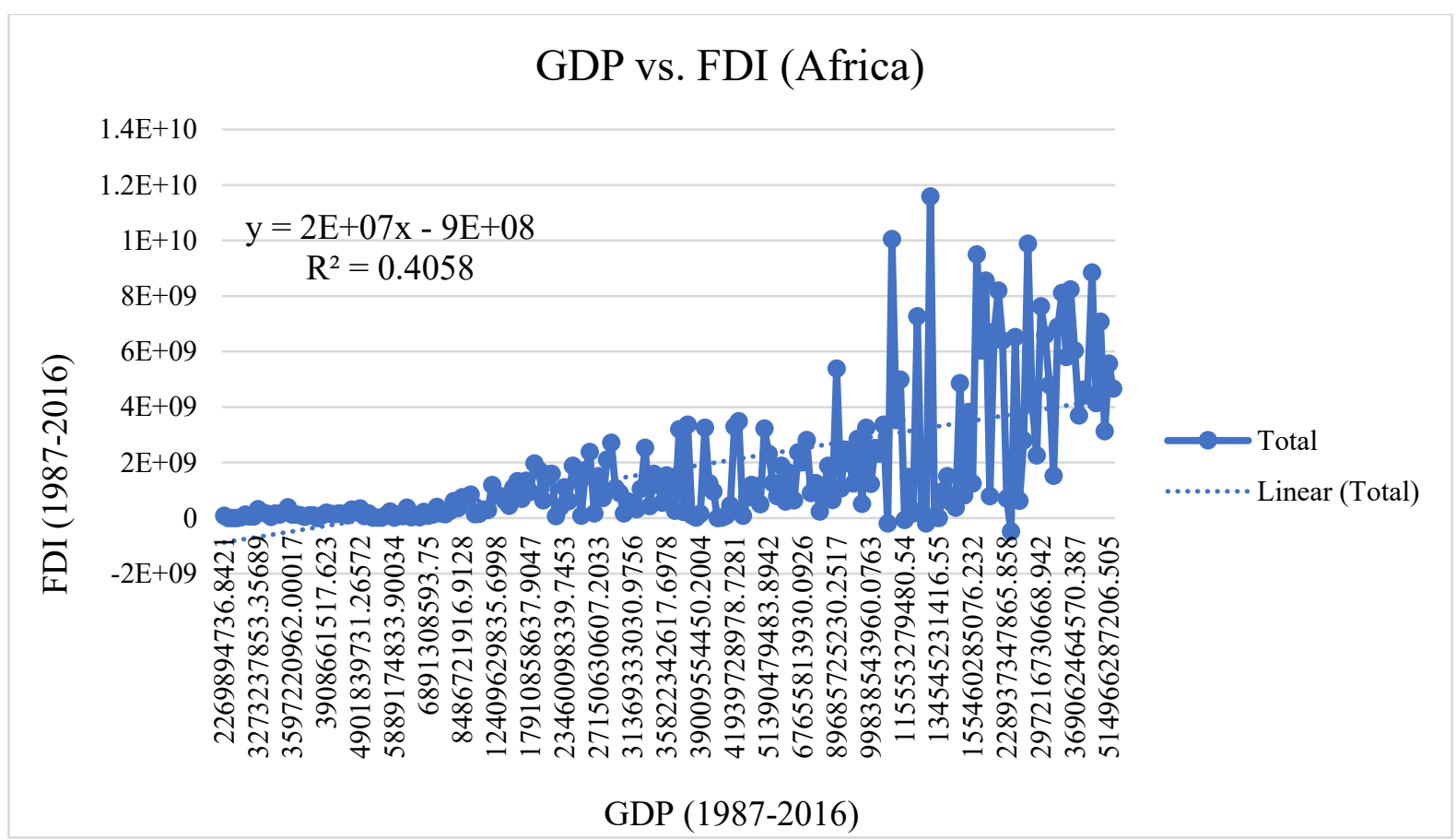

Figure 2.2: FDI vs. GDP in Africa (1987-2016) 


\section{The Case for Asia}

The Asian countries included in this study are China, India, Indonesia, Malaysia, Pakistan, Philippines, Qatar, Russia, Thailand and Turkey. According to the Financier Worldwide Magazine (2015), FDI is a major source of development finance that contributes "handsomely" to the economic growth of several countries. Asia, in particular, has gained substantially from FDI flows into the region. In a recent United Nations report, the World Investment Report 2017, FDI inflows to developing Asia were expected to increase that year by 15\%, to $\$ 515$ billion. Per the report, this boost is an indication of investor confidence, based on an "improved economic outlook in major Asian economies." China, specifically, has evolved from simply a recipient of FDI to a major donor (see Table 3.1).

\begin{tabular}{|c|r|r|}
\hline \multirow{2}{*}{ Inward } & CHINA FLOWS IN FDI (\$ millions) \\
\cline { 2 - 3 } & $156,249.00$ & 2007 \\
\hline Outward & $17,155.00$ & $217,203.00$ \\
\hline
\end{tabular}

From China's 10-year depiction above, a vague deduction can be made that the country sees a corresponding increase in FDI inflows as it boosts its outward investments. If it is true that FDI contributes to economic growth, then this phenomenon validates Encinas-Ferrer and Villegas-Zermeño (2015)'s theory of a bi-directional relationship between FDI and GDP. Rising FDI within a country increases its GDP, and thus allows local corporations to expand abroad. In turn, this creates an attractive environment for the home country to receive investors. Figure 3.1 shows the picture of GDP per capita and FDI per capita in Asia between 1987 and 2016. The two variables run relatively parallel to each another until the early 2000s when FDI per capita rises above GDP per capita, and then dramatically falls post-Financial Crisis ${ }^{5}$. The regression analysis (Figure 3.2 ) further reveals that only a quarter $(25.84 \%)$ of Asian GDP is the result of FDI. Interestingly, however, eliminating anomalies like China and Qatar from the pool of Asian countries paints a dramatically different picture. China, for one, received net FDI of over $\$ 170$ billion in 2016, nearly quadruple the next biggest player, India. China's GDP in the same year is also about five times India's. Therefore, China is a large player that skews the outcome of the linear charts. It is fair to say that China is the biggest driver of FDI after 2005 (Figure $3.1)$.

Figures $3.3 \& 3.4$, however, present the case for Asia without China and Qatar, resulting in a stronger positive correlation between FDI per capita and GDP per capita (Figure 3.3). Eliminating Qatar resolves the steep decline in regional FDI per capita. This is a valid assessment, given Qatar's reputation as an oil-driven economy; petroleum and natural gas account more than $70 \%$ of total government revenue, over $60 \%$ of GDP and an estimated $85 \%$ of export earnings in 2016 (IMF, 2018). Almfraji, Almsafir and Yao (2014) explore, in great detail, the case of Qatar, concluding that FDI inflows and economic growth in the country interact with each other in a relatively long-term. From the second regression, the new ${ }^{+} \mathrm{R}$-squared value of 0.4078 also reflects a stronger relationship between FDI and GDP in the remaining Asian countries. This is true because these eight countries are shown to have more closely related ties, without the interference of the two anomalies.

\footnotetext{
${ }^{5}$ The Financial Crisis was period of global economic recession spanning 2007-2008 during which subprime mortgage market in the U.S. collapsed, and spiraled into widespread financial crises across North America, Europe and Asia. It has been described by economists as the worst economic disaster since the Great Depression.

+ Adjusted Charts for Asia, excluding China and Qatar
} 


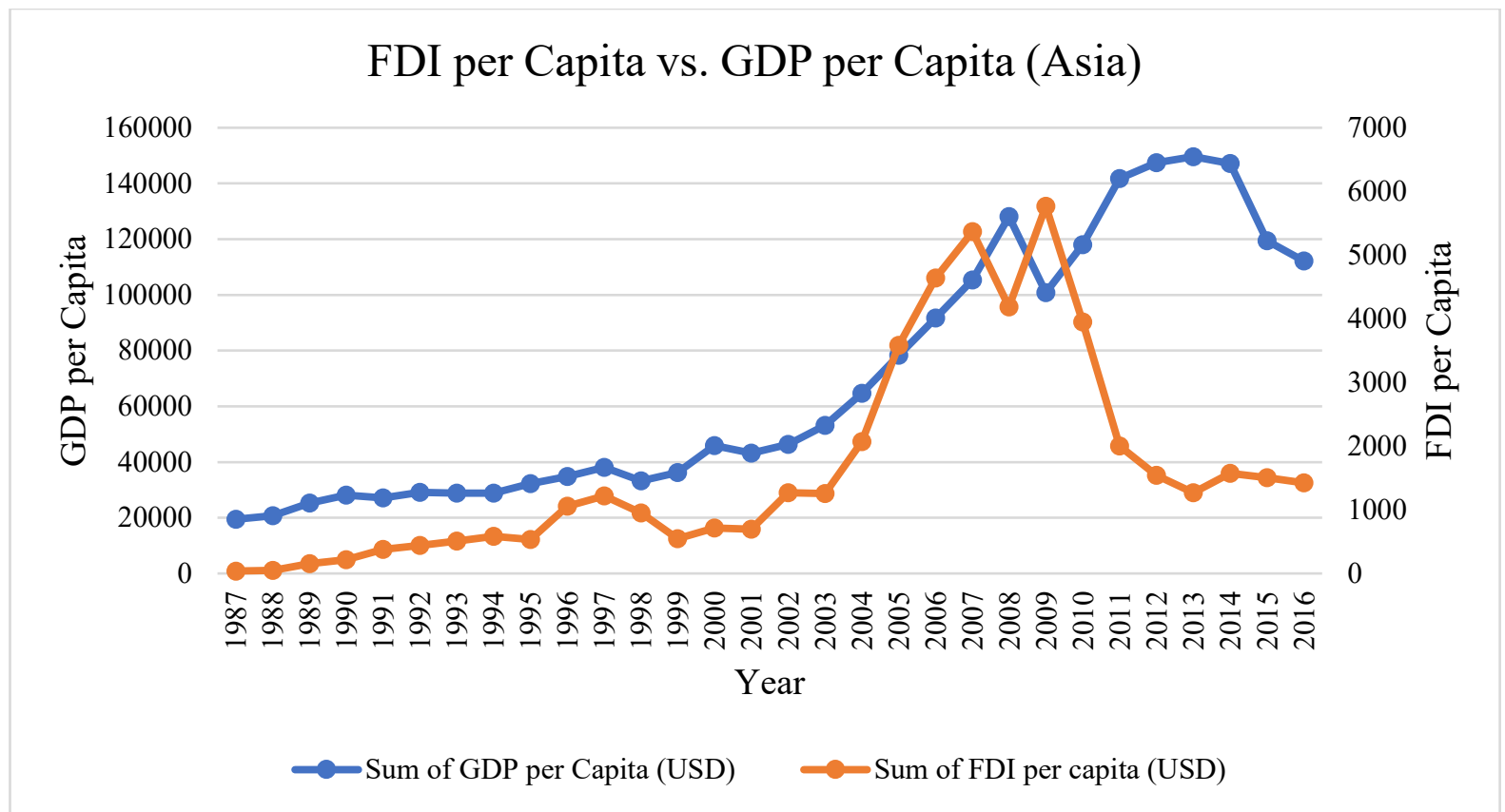

Figure 3.1: Correlation of GDP per capita and FDI per capita in Asia (1987-2016)

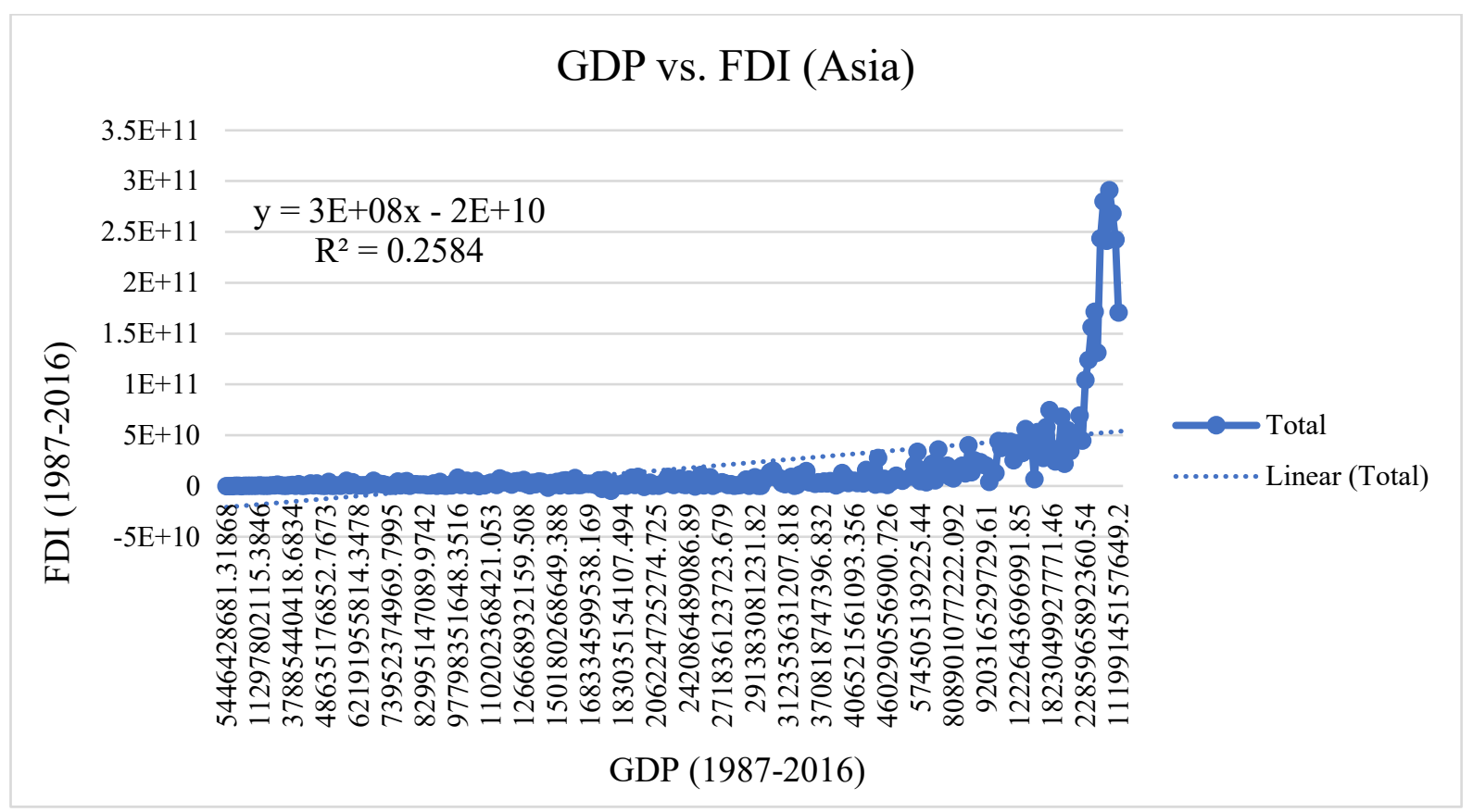

Figure 3.2: FDI vs. GDP in Asia (1987-2016) 


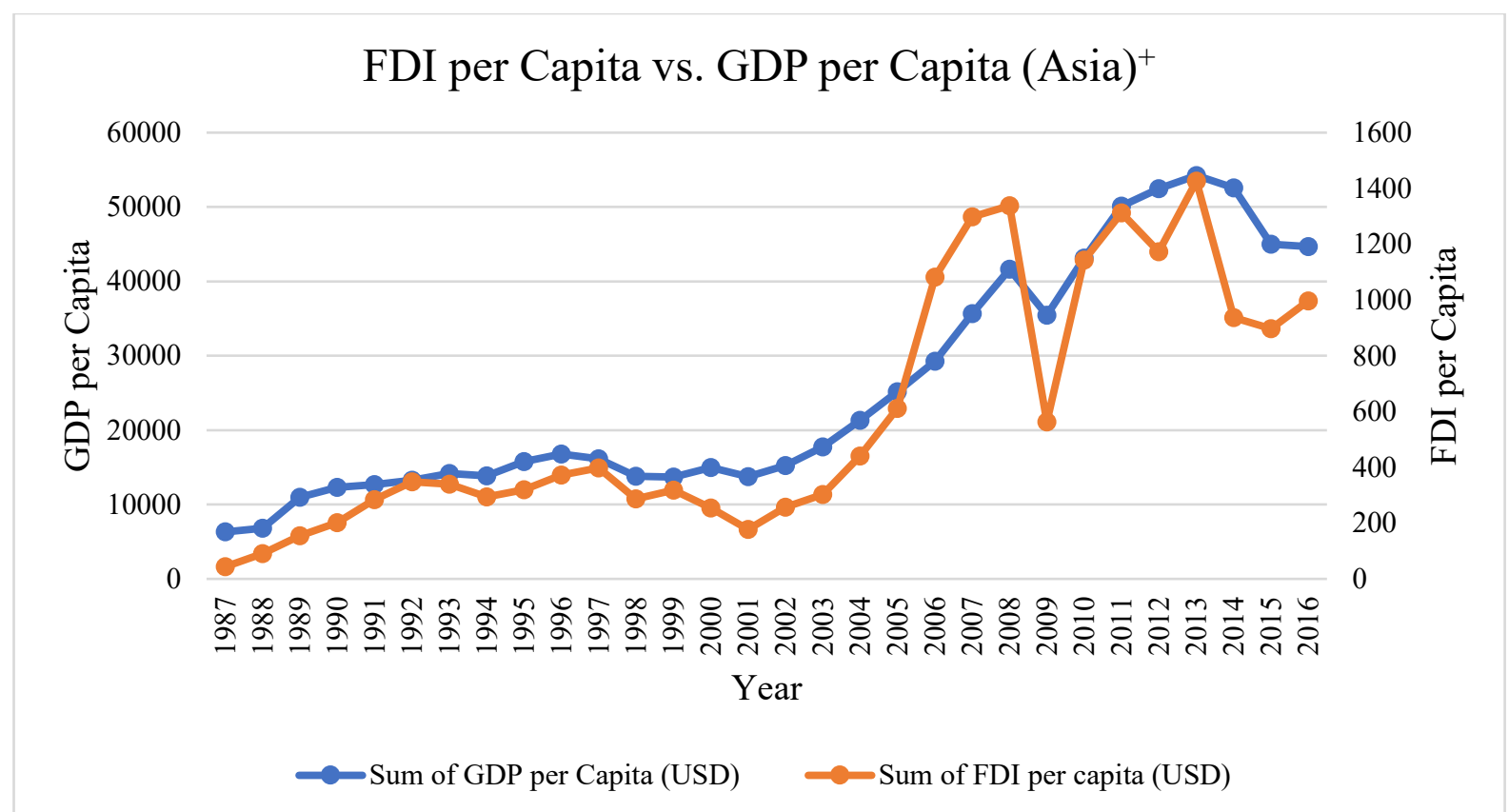

Figure 3.3: Correlation of GDP per capita and FDI per capita in Asia, without China and Qatar (1987-2016)

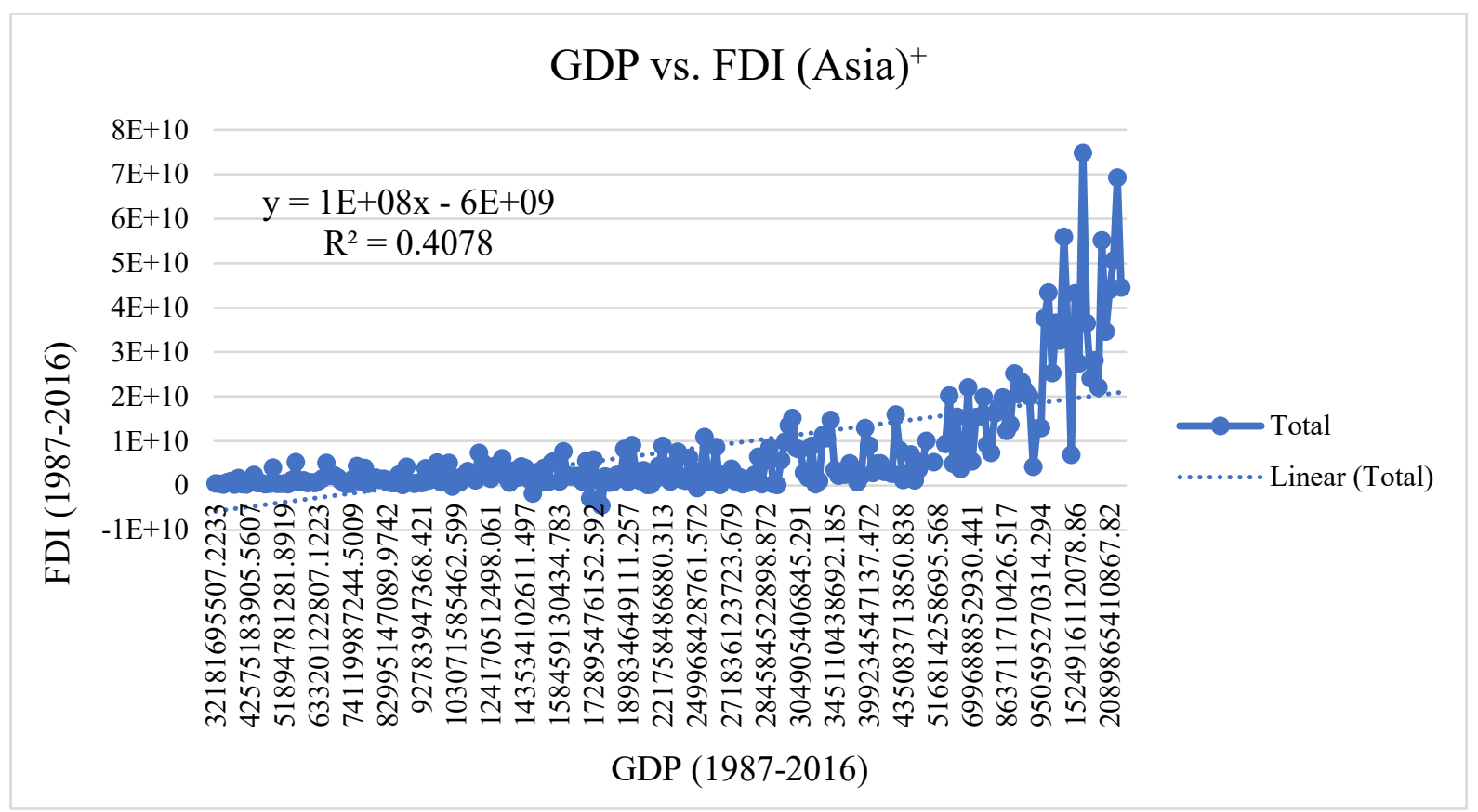

Figure 3.4: FDI vs. GDP in Asia, without China and Qatar (1987-2016)

\section{The Case for Europe}

In 1993, the European Union (EU) achieved a Single Market to facilitate "the movement of goods, services, people and money" (EU, 2018). At the time of this paper's authorship, the EU is composed of 28 member states, including Great Britain, which is likely to secede following the Brexit vote. Most EU member states, particularly in Western Europe, have enjoyed sustainable economic growth stemming from the days of ancient Britannic, Italian Colonial, Spanish and German Empires. These empires invaded and colonized diverse civilizations across the globe, from which they gained vast resources to build lasting, formidable economies (Betocchi \& Canova, 2002). 
This research looked at Czech Republic, Poland, Russia, Turkey and Ukraine as emerging economies in Europe. Although Greece and Hungary were initially considered for this study, the recent Greek Governmentdebt Crisis and inconsistent data on Hungary were bases to exclude the two countries. In the case for Europe, Figure 4.1 demonstrates a close correlation between FDI and GDP from 1987 until about a decade ago. In 2009 when the Greek Debt Crisis struck, there were negative spillovers into neighboring countries Cyprus, Ireland, Portugal and Spain, as some of these countries were unable to make payments on government bonds, prompting a bailout by other member states (De Bruyckere, Gerhardt, Schepens, \& Vander Vennet, 2012).

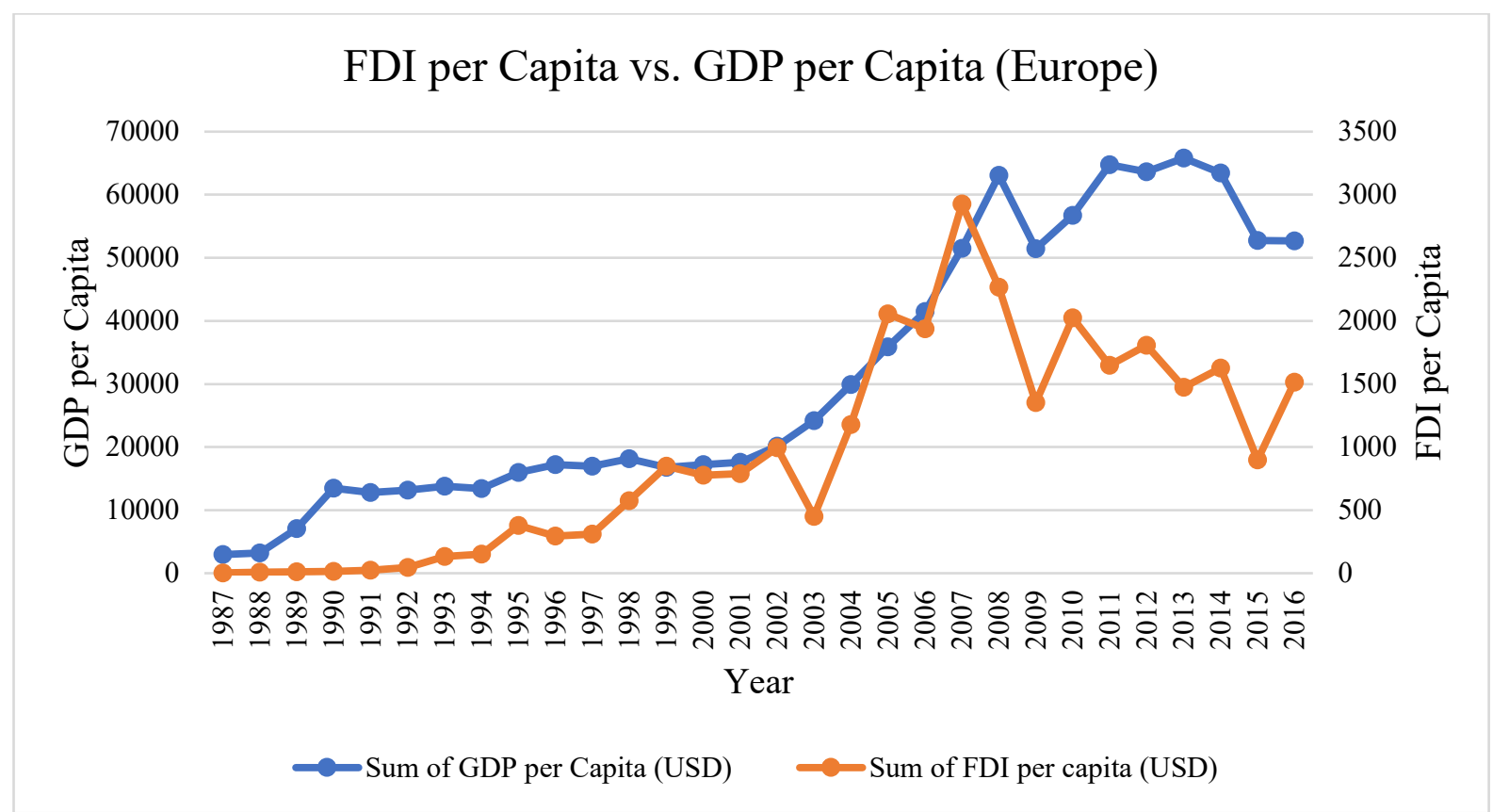

Figure 4.1: Correlation of GDP per capita and FDI per capita in Europe (1987-2016)

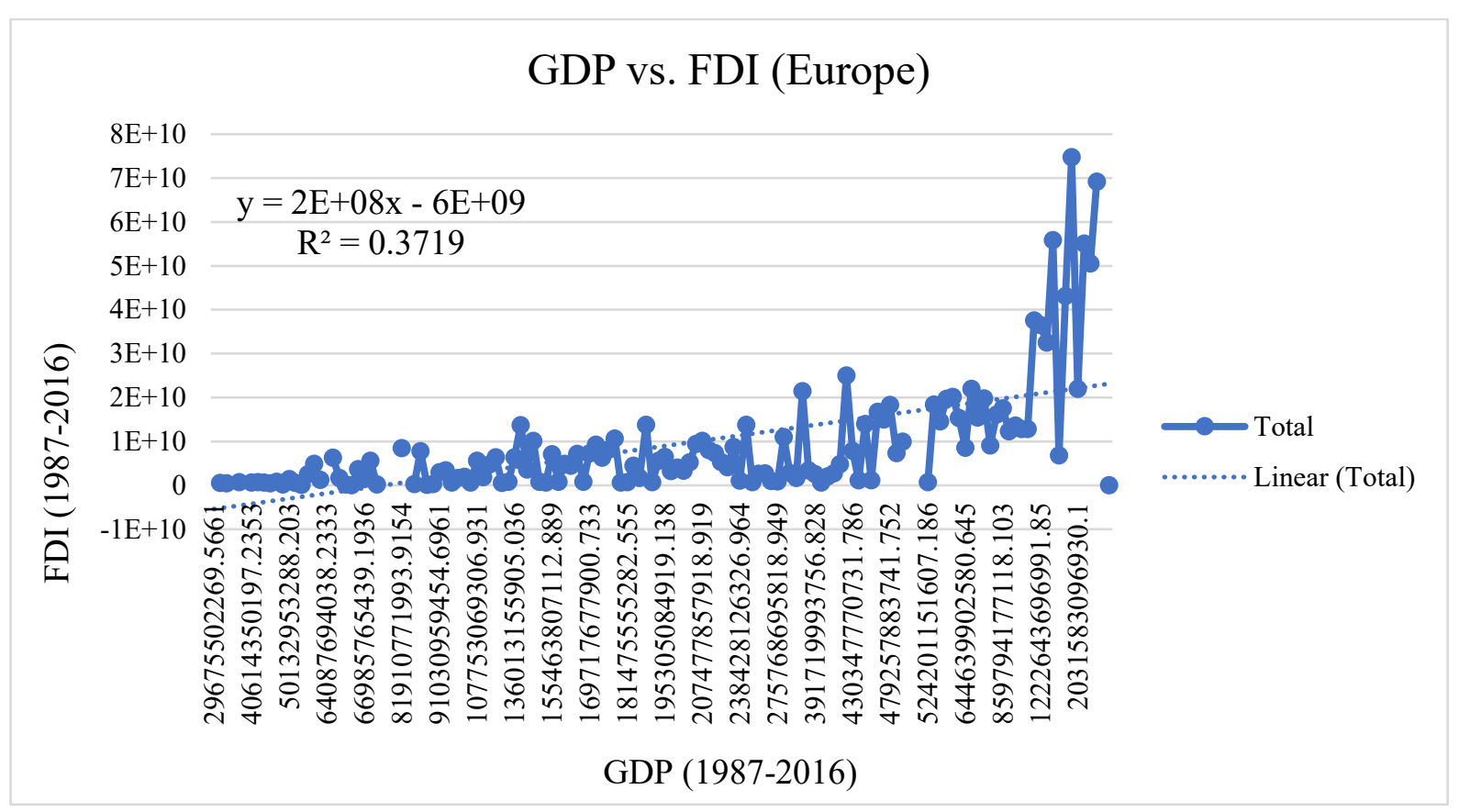

Figure 4.2: FDI vs. GDP in Europe (1987-2016) 
In 2014, Ukraine endured massive protests and political unrest after controversies arose over the Ukraine-EU Association Agreement ${ }^{6}$. Weakened investor confidence in the EU region signaled by that series of events and the United Kingdom's subsequent decision to leave the European Union is reflected in Figure 4.1 above. From the regression (Figure 4.2), there appears to be a weak causal relationship between European GDP and FDI ( $\mathrm{R}^{2}$ of $\left.37 \%\right)$. Individually, Russia, Ukraine, and Turkey seem to exhibit a stronger correlation between GDP and FDI at $68.27 \%, 62.86 \%$, and $63.84 \%$ respectively. Lower R-squared values for Czech Republic and Poland weaken the overall relationship between the two variables.

\section{The Case for Central \& South America}

The case for Central \& South America is peculiar as it pertains to FDI. Until the 1990s, majority of the people supported, and governments in the region implemented policies that restricted the inflow of FDI. These policies included the introduction of Import Substituting Industrialization (I.S.I.) ${ }^{7}$ in Brazil, a program created to protect local (Brazilian) industry by reducing international trade (Candler, 1996). The supporters of this program argued that the trade between Latin America and the developed world resulted in Latin America incurring more debt without much development. Similarly, in Mexico, natives had coined the phrase, "Mexico, mother of foreigners and the stepmother of Mexicans" to protest the negative impact of foreign trade on local industry (Mabry, 1994). As Candler (1996) writes, economic policy, as laid out by Europeans during much of Latin America's early, unsophisticated post-colonial years, championed the interests of agro-exporters. This was a pragmatic approach by the colonists as it particularly fueled Portuguese interests - at the expense of Brazil's.

However, the long-protected industry with a lack of a strong technological base began to decline. To finance their budgets, the governments started to print money, leading to hyper-inflation. This rhetoric began to change in 1993. For example, then Brazilian finance minister, Fernando Henrique Cardoso, employed FDIfriendly policies through reducing tariffs. This new strategy decreased inflation from over $2,400 \%$ to under $25 \%$, and the success of these policies could also be proven by the fact that Cardoso went on to win the presidential election in 1995. Indeed, I.S.I. was unworkable and would hinder the development of South American economies in the capitalist world system. Again, in Mexico, as the government began to reopen its doors to foreign investment in the late 1980s (New York Times, 1986), the Latin American country began to see a corresponding spike in economic growth (see The Case for Mexico). The Figure 5.1 shows an incredible increase in the FDI inflow in this continent from 1993 until the financial crisis. Economic growth increased during this time as well, mostly due to the new policies. Thus, one can conclude, in an integrated global economy, one country's development is strongly tied to several other countries' development. Eco-nationalistic policies that restrict international trade only do well to alienate the subject country.

For the purpose of this study, Central and South America comprise Argentina, Brazil, Chile, Colombia, Ecuador, Mexico, Panama, Peru, and Venezuela. Despite a near mirror image between FDI per capita and GDP per capita (Figure 5.1), the R-squared value of 0.3658 from the regression indicates a fairly weak causal relationship. A follow-up investigation revealed two things. Firstly, that Brazil, Chile, Colombia, Mexico, Panama, and Peru each demonstrated a strong relationship between FDI and GDP ( $\mathrm{R}^{2}$ above $75 \%$ ), while Argentina, Ecuador, and Venezuela each recorded an R-squared value between 15-38\%. Secondly, we discovered that although the former six nations each recorded substantially higher R-squared values [indicating a strong relationship], collectively, the same six, grouped together, yield an R-squared value of $45.75 \%$, nearly two-thirds their mean R-squared of $78.45 \%$.

These revelations lend to the limitations of a regression analysis to determine causality. More likely than not, this approach is more accurate for observing individual countries, rather than clustered regions (see the case for Mexico). We see that our linear charts, due to the aggregation of countries, reflect an average trend for clusters of regions, without any weighting for more impactful economies in the region. This is at least true in South and Central America, where three out of the nine nations selected undermine the stronger relationship [between FDI and GDP] of the six others.

\footnotetext{
${ }^{6}$ The Association Agreement is an economic \& political partnership between the European Union and Ukraine.

${ }^{7}$ Import Substitution Industrialization refers to an economic policy program that promotes domestic production of goods and services by restricting the import of those products.
} 


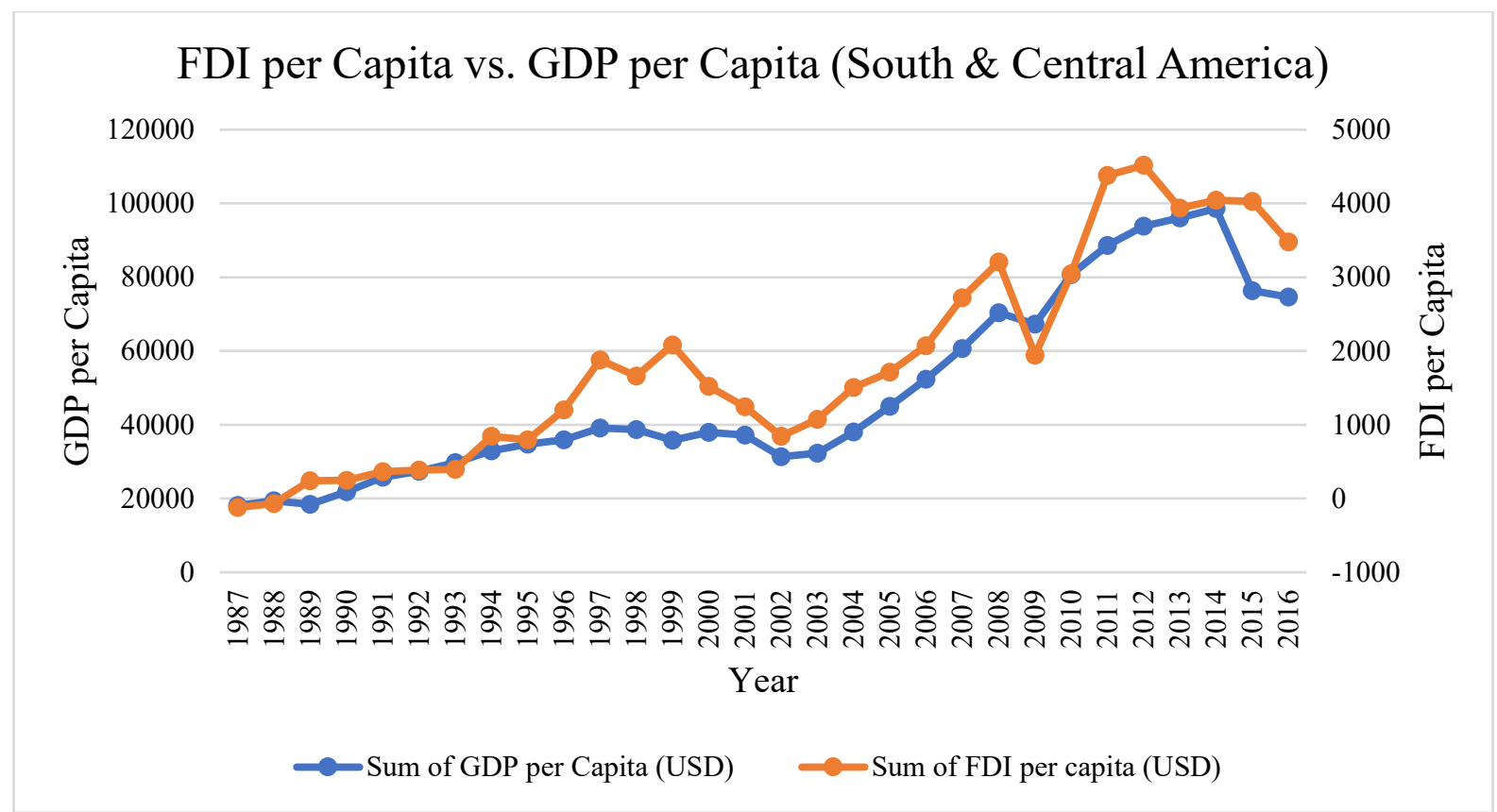

Figure 5.1: Correlation of GDP per capita and FDI per capita in South \& Central America (1987-2016)

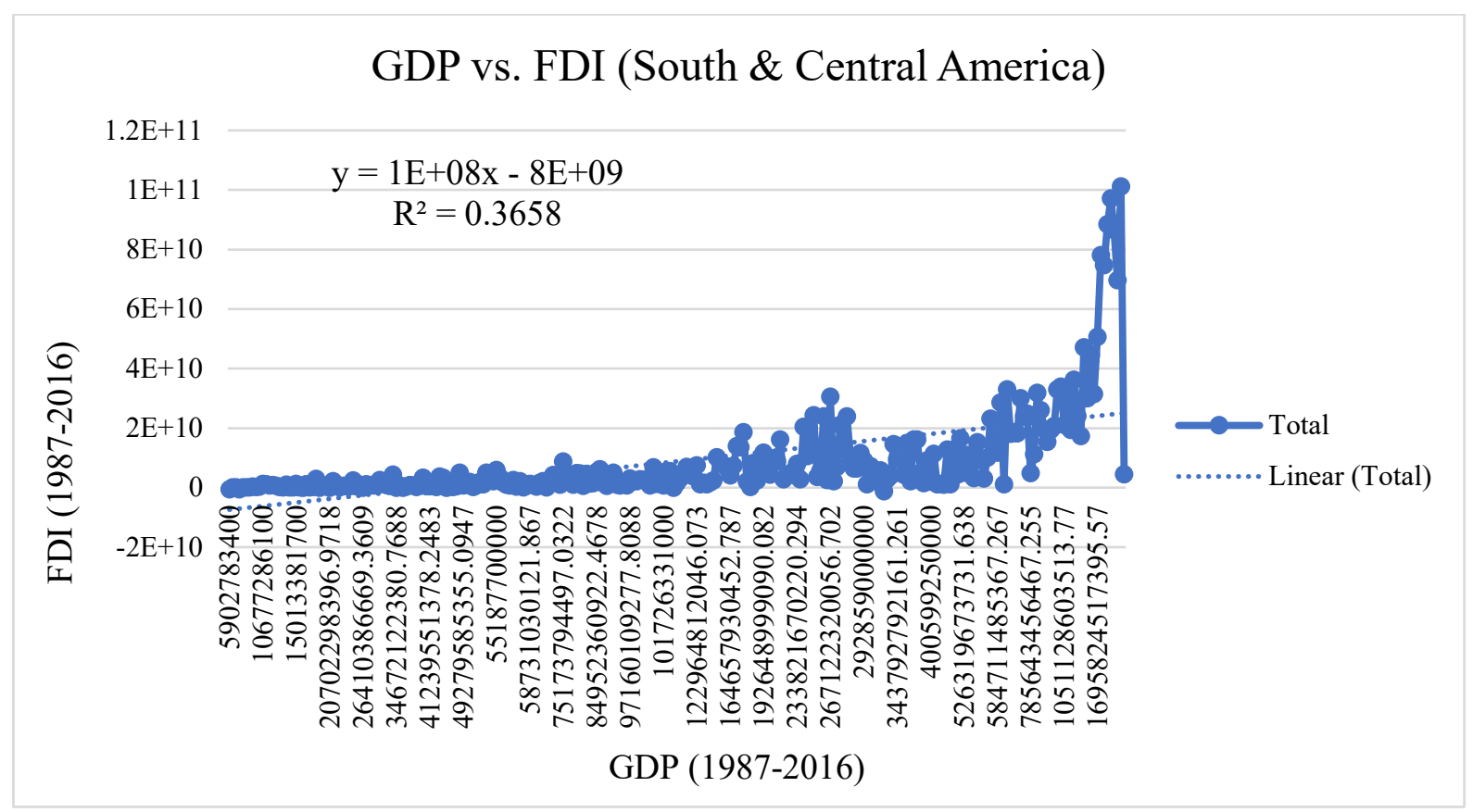

Figure 5.2: FDI vs. GDP in South \& Central America (1987-2016) 


\section{The Case for Mexico}

This research project afforded the authors the opportunity to collect some qualitative data in Mexico. Historically, the Mexican economy has benefitted from a strong relationship with the United States, one of its single largest sources of FDI inflows. Per the National Statistics Institute (INEGI), Mexico received approximately $40 \%$ of FDI in 2016 totaling $\$ 10.4$ billion from the United States. The US International Trade Administration that "most foreign investment flows to northern states near the US border, where most exportoriented manufacturing and assembly plants are located, or to Mexico City..." (Department of Commerce). This statement concurs with the work of Rivera and Castro (2012) on the effects of FDI on income inequality in Mexico.

On July 17, 2017, the Office of the United States Trade Representative (USTR) released a 17-page Summary of Objectives for the NAFTA Renegotiation. The document's stated intent is to seek the welfare of America and its workers (USTR, 2017). The threat of a renegotiation or possibly, a US withdrawal from the deal is real and can impact nearly half of Mexico's FDI inflows. Mexican businesses are well aware of this and are beginning to implement countermeasures. In a conversation with Raúl Cortés, International Freight Coordinator for Han Ocean ${ }^{8}$ in Mexico, he disclosed that "while the United States' stance on NAFTA ${ }^{9}$ has not had any impact on our business, the country's present eco-nationalistic rhetoric is pushing us [and other Mexican multinationals] to pursue new partnerships around us, such as with Peru and Colombia. Further, China is taking advantage of these opportunities to do international business." Currently, Mexico's nominal GDP per capita has soared from $\$ 1,742.34$ in 1987 to $\$ 8,208.56$ in 2016 . FDI per capita has risen accordingly from $\$ 14.71$ to $\$ 266.04$ over the same period (Figure 6.1). The regression (Figure 6.2) further proves that $75.82 \%$ of the Mexican GDP from 1987-2016 is related to FDI activity.

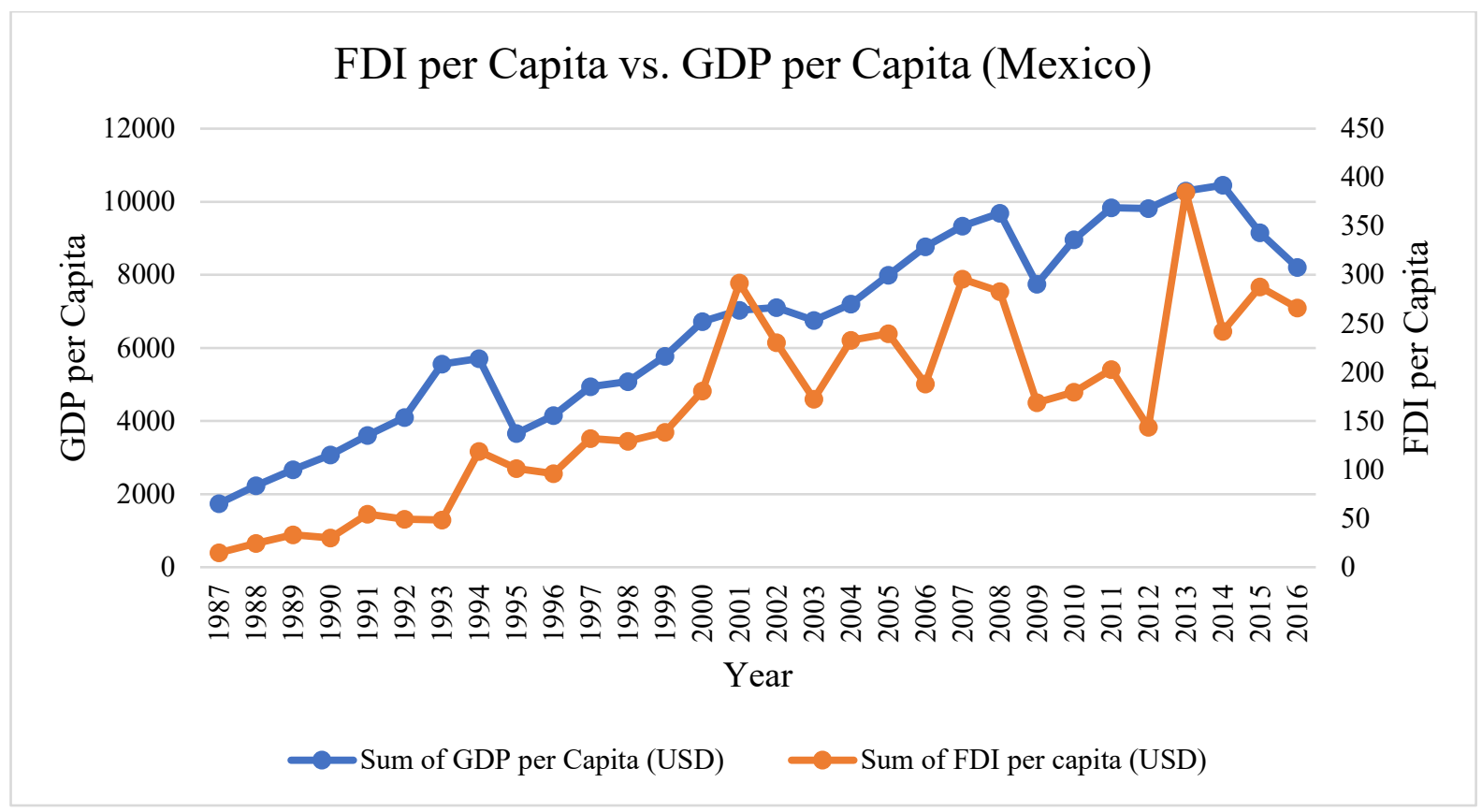

Figure 6.1: Correlation of GDP per capita and FDI per capita in Mexico (1987-2016)

\footnotetext{
${ }^{8}$ Han Ocean is a South Korean international logistics and Import/Export firm with an operations base in Mexico.

${ }^{9}$ NAFTA is the North American Free Trade Agreement by Canada, Mexico and the US, creating a trilateral trade bloc.
} 


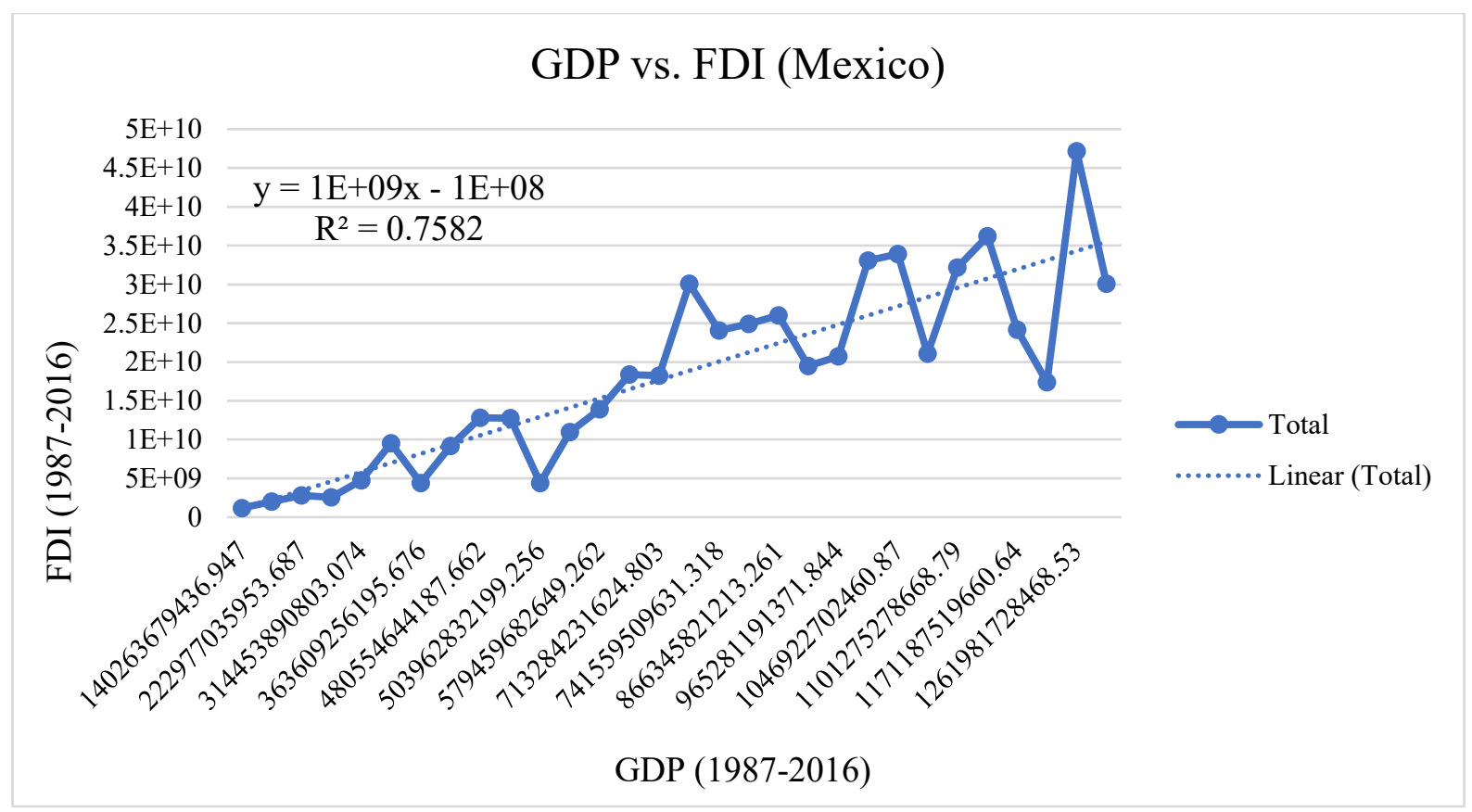

Figure 6.2: Correlation of GDP per capita and FDI per capita in Mexico (1987-2016)

\section{Conclusion}

Based on the discussion of our findings, we can conclude that economic growth, as measured by GDP, is a function of multiple factors that vary from country to country and by the span of time. FDI is one prominent factor that influences economic growth, as demonstrated in our data analysis. Other factors such as political climate and level of technological and infrastructural development can facilitate the ease of doing business in a foreign country. Our analysis also reveals that although FDI tends to mimic economic growth, it is not distinctively the determinant of GDP, and it is difficult to establish a causal relationship. In some instances, positive economic growth is an attractor of FDI. Encinas-Ferrer and Villegas-Zermeño (2015) describe this as a bi-directional relationship. We call this, in fact, a cyclical relationship where economic growth, which attracts foreign direct investment leads to even stronger economic growth, as is the case for China and the United States. China, by itself, yields an R-squared value of 0.8159 on the regression model. This is a strong indication of a causal relationship between FDI and GDP. This may be due to the Chinese government's strong synergy with Chinese businesses, and an aggressive approach to expanding abroad. Additionally, recent US efforts toward eco-nationalism may create a conducive global environment for China to penetrate new markets previously dominated by the US. Despite this paper's findings, we acknowledge that a conjugate graph and regression analysis are insufficient for a conclusive analysis. Further resources and advanced statistical tools such as the Granger Causality test will allow us to gather and analyze more quantitative and qualitative data.

\section{Recommendation}

Following our data analysis and engagement of other scholarly work on the topic, the authors have the following recommendations for how emerging economies can attract increased FDI. Since the data shows a typically positive correlation between FDI and economic growth indicators, emerging economies, especially in Asia and Africa, are encouraged to adopt economic policies and techniques that promote and accommodate business from foreign investors. Previous research also shows that FDI inflow in a country highly depends on the host government's reputation. Economically conservative governments tend to be more stable and predictable, thus minimizing the element of uncertainty. We concur with Griebeler and Wagner (2017) that populist governments should desist from extreme fiscal risks to boost investor confidence. Research by Teli (2013) further proves that retailers in countries like India will be able to survive the competition brought in by foreign companies (Teli, 2013). 
References

Adegoke, Y. (2018). Africa's economic outlook is promising for 2018, but there are clouds on the horizon. Quartz Africa. Retrieved from https://qz.com/1179387/africas-economic-outlook-is-promising-for-2018but-there-clouds-on-the-horizon/

Almfraji, M. A., \& Almsafir, M. K. (2014). Foreign direct investment and economic growth literature review from 1994 to 2012. Procedia - Social and Behavioral Sciences, 129, 206-213. 10.1016/j.sbspro.2014.03.668

Almfraji, M. A., Almsafir, M. K., \& Yao, L. (2014). Economic growth and foreign direct investment inflows: The case of Qatar. Procedia - Social and Behavioral Sciences, 109, 1040-1045. 10.1016/j.sbspro.2013.12.586

Bertocchi, G., \& Canova, F. (2002). Did colonization matter for growth? An empirical exploration into the historical causes of Africa's underdevelopment. European Economic Review, 10.1016/S00142921(01)00195-7

Bloomberg (2013). The top 20 emerging markets. Retrieved from https://www.bloomberg.com/news/photoessays/2013-01-31/the-top-20-emerging-markets

Business Dictionary (2018). Coefficient of determination $\left(\mathrm{r}^{2}\right)$. Retrieved from http://www.businessdictionary.com/definition/coefficient-of-determination-r2.html

Candler, G. G. (1996). Cardoso, dependency theory and Brazil. Indiana University; University of North Florida Department of Political Science and Public Administration www.unf.edu/ g.candler/articles/FHC-RM.pdf

Data Market (2014). J.P. Morgan Emerging Markets Bond Index (EMBI+). Retrieved from https://datamarket.com/data/set/1dme/jp-morgan-emerging-markets-bond-indexembi\#!ds=1dme!x88=7.k.b.9.a.i.4.c.f.g.e.m.2.d.5.h.8.n\&display=choropleth\&map=world\&classifier $=$ nat ural\&numclasses $=5$

De Bruyckere, V., Gerhardt, M., Schepens, G., \& Vander Vennet, R. (2012). Bank/sovereign risk spillovers in the European debt crisis. Working Paper Research, 232 Retrieved from https://www.econstor.eu/handle/10419/144444

Encinas-Ferrer, C., \& Villegas-Zermeño, E. (2015). Foreign direct investment and gross domestic product growth. Procedia Economics and Finance, 24, 198-207. 10.1016/S2212-5671(15)00647-4

Financier Worldwide Magazine (2015). FDI in Asia. Retrieved from https://www.financierworldwide.com/fdi-in-asia/\#.WtehUooXahB

Griebeler, M. d. C., \& Wagner, E. M. (2017). A signaling model of foreign direct investment attraction. EconomiA, 10.1016/j.econ.2017.04.001 Retrieved from https://www.sciencedirect.com/science/article/pii/S1517758017300048

Haroon Bhorat, Grieve Chelwa, Karmen Naidoo, \& Benjamin Stanwix (2015). Resource dependence and inequality in Africa: Impact, consequence and potential solutions. Africa Economic Conference.

International Trade Administration (2017). Mexico - Openness to and restriction on foreign investment. United States Department of Commerce. Retrieved from https://www.export.gov/apex/article2?id=Mexico-Openness-to-and-Restriction-on-Foreign-Investment

Jadhav, P. (2012). Determinants of foreign direct investment in BRICS economies: Analysis of economic, institutional and political factor. Procedia - Social and Behavioral Sciences, 37, 5-14. 10.1016/j.sbspro.2012.03.270

Juarez Rivera, C. G., \& Angeles Castro, G. (2013). Foreign direct investment in Mexico: Determinants and its effect on income inequality. Contaduria Y Administracion, 58(4), 201-222. 10.1016/S01861042(13)71239-7

Kayizzi-Mugerwa, S. (2001). Is Uganda an emerging economy? A report for the OECD project emerging Africa. Nordiska Afrikainstitutet Research Report, No.118 Retrieved from https://gup.ub.gu.se/publication/36651

Krishnakumar, D., Sethi, M., \& Chidambaran, N. K. (2014). Foreign direct investment and strategic partnerships: Cross-border acquisitions between India and Africa. Procedia - Social and Behavioral Sciences, 157, 45-54. 10.1016/j.sbspro.2014.11.008

Lipsey, R. E. (2001). Foreign direct investment and the operations of multinational firms: Concepts, history, and data. NBER working paper series: International Trade and Investment. 10.3386/w8665

Mabry, D. J. (1994). Porfirio Diaz. Historic World Leaders, Detroit and London, Gale Research, Inc. 
Malikane, C., \& Chitambara (2017). Foreign direct investment, productivity, and the technology gaps in African economies. Journal of African Trade 61-74, 10.1016/j.joat.2017.11.001

MSCI (2018). Morgan Stanley Capital International Emerging Markets Index. Retrieved from https://www.msci.com/emerging-markets

Nandi, S. (2012). Comparative analysis of foreign direct investment trends in emerging economies. Procedia Social and Behavioral Sciences, 37, 230-240. 10.1016/j.sbspro.2012.03.289

OECD Data (2018). FDI flows. Organisation for Economic Development and Co-operation. Retrieved from https://data.oecd.org/fdi/fdi-flows.htm

Stockton, W. (1986). Mexico tries an open-door policy. New York Times. Retrieved from https://www.nytimes.com/1986/02/16/business/mexico-tries-an-open-door-policy.html

Teli, R. B. (2014). A critical analysis of foreign direct investment inflows in India. Procedia - Social and Behavioral Sciences, 133, 447-455. 10.1016/j.sbspro.2014.04.211

The World Bank (2018). Foreign direct investment, net inflows (BoP, current US\$). World Bank Data. Retrieved from https://data.worldbank.org/indicator/bx.klt.dinv.cd.wd

UNCTAD (2017). World investment report 2017: Investment and the digital economy. United Nations Conference on Trade and Development. Retrieved from http://unctad.org/en/PublicationsLibrary/wir2017 overview en.pdf

USTR (2017). Summary of objectives for the NAFTA renegotiation. Office of the United States Trade Representative. Executive Office of the President. Retrieved from https://ustr.gov/sites/default/files/Press/Releases/NAFTAObjectives.pdf

Waldkirch, A. (2008). The effects of foreign direct investment in Mexico since NAFTA. Munich Personal RePEc Archive. Retrieved from http://mpra.ub.uni-muenchen.de/7975/

World Economic Outlook Database (2017). Report for Qatar. International Monetary Fund. Retrieved from http://www.imf.org/external/pubs/ft/weo/2017/01/weodata/weoselser.aspx?c=453\&t=1 